\title{
PENGARUH KAMPANYE POLITIK PASANGAN MURSIL-TENGKU INSYAFUDDIN TERHADAP PERILAKU PEMILIH PADA PILKADA ACEH TAMIANG TAHUN 2017
}

\author{
AZWANIL FAKHRI \\ juanfakhri@gmail.com \\ Universitas Sumatera Utara
}

\begin{abstract}
ABSTRAK
Kajian mengenai pengaruh kampanye politik terhadap perilaku pemilih sejauh ini masih jarang dilakukan dalam konteks Pemilu Kepala Daerah di Aceh. Penelitian ini dilakukan untuk menganalisis pengaruh kampanye politik Pasangan Mursil-Tengku Insyafuddin terhadap perilaku pemilih pada Pilkada Aceh Tamiang Tahun 2017. Peneliti menggunakan metode korelasional untuk menganalisis temuan hasil survei yang telah dilakukan kepada 400 orang responden terpilih. Uji hipotesis dianalisis menggunakan rumus regresi berganda dan rumus koefisien korelasi Spearman dengan bantuan perangkat lunak SPSS for Windows 24.0. Hasil penelitian menemukan variabel kampanye politik berpengaruh terhadap perilaku pemilih. Berdasarkan interpretasi nilai Guilford, hasil uji koefisien korelasi antar variabel juga menemukan nilai keeratan hubungan antar variabel berada di rentang rendah sampai dengan sedang dengan tingkat hubungan yang signifikan. Hasil penelitian ini membuktikan hipotesis yang diajukan bahwa kampanye politik berpengaruh terhadap perilaku pemilih.
\end{abstract}

\section{Kata Kunci: Pilkada, Pengaruh, Kampanye Politik, Perilaku Pemilih}

\begin{abstract}
Studies on the influence of political campaigns on voter behavior so far have rarely been carried out in the context of Regional Head Elections in Aceh. This study was conducted to analyze the influence of the Mursil-Tengku Insyafuddin Couple's political campaign on voter behavior in the Aceh Tamiang Regional Election in 2017. The researcher used the correlational method to analyze the findings of the survey results that had been conducted to 400 selected respondents. Hypothesis testing was analyzed using the multiple regression formula and the Spearman correlation coefficient formula with the help of SPSS for Windows 24.0 software. The results of the study found that political campaign variables influence voter behavior. Based on the interpretation of the Guilford value, the results of the correlation coefficient test between variables also found the value of the closeness of the relationship between variables in the low to moderate range with a significant level of relationship. The results of this study prove the hypothesis put forward that political campaigns influence voter behavior.
\end{abstract}

Keywords: Election, Influence, Political Campaign, Voter Behavior. 


\section{PENDAHULUAN}

Pemilihan kepala dan wakil kepala daerah secara langsung merupakan agenda penting dan strategis dalam membangun pemerintahan daerah yang demokratis. Pemilihan secara langsung telah membuka ruang bagi masyarakat untuk memilih dan berkehendak siapa yang akan menjadi pemimpin daerahnya kelak. Ini adalah sebentuk pengenjawantahan nyata asas responsibilitas dan akuntabilitas penyelenggaraan kedaulatan rakyat. Ia menjadi pilar penting dalam pembangunan di daerah untuk mendorong terbentuknya tatanan serta kerjasama dan kemitraan yang sinergis dan seimbang antara seluruh pelaku dan pihak yang terlibat dalam pembangunan daerah tersebut.

Pemilihan kepala daerah adalah rekrutmen politik, yakni cara penyeleksian rakyat terhadap orang-orang yang mencalonkan diri sebagai kepala daerah, baik gubernur dan wakil gubernur, atau bupati/walikota beserta wakilnya. Aktor utama dalam rekrutmen politik ini adalah rakyat pemilih, partai politik, dan calon kepala daerah. Rakyat dalam hal ini -idealnya, harus kritis terhadap caloncalon yang ada, bukan hanya saat memilih saja, tetapi juga setelah calon terpilih sebagai kepala daerah. Untuk itulah dalam rekrutmen politik melalui pemilihan memberikan adanya hak kepada rakyat untuk memilih. Hak memilih ini meminta adanya partisipasi politik aktif dari rakyat.

Menurut Bolgherini, partisipasi politik adalah "a series of activities related to political life, aimed at influencing public decisions in a more or less direct way-legal, conventional, pacific, or contentious" (dalam Calise \& Lowi, 2010:169). Menurutnya, partisipasi politik adalah segala aktivitas yang berkaitan dengan kehidupan politik, yang ditujukan untuk memengaruhi pengambilan keputusan baik secara langsung maupun tidak langsung -dengan cara legal, konvensional, damai, ataupun memaksa. Budiardjo (2008:369) berpendapat bahwa partisipasi politik merupakan implementasi dari penyelenggaraan politik yang absah oleh rakyat. Anggota masyarakat yang berpartisipasi dalam proses politik melalui pemilu terdorong oleh keyakinan 
bahwa melalui kegiatan bersama itu kepentingan mereka akan tersalur atau sekurangnya akan diperhatikan.

Mereka -masyarakat, percaya bahwa kegiatan itu memiliki efek yang disebut dengan efikasi politik (political efficacy). Dari aspek sosiologi politik, lebih banyak rakyat turut serta berpartisipasi dalam politik menunjukkan bahwa pendidikan politik berhasil. Partisipasi yang semakin besar juga menunjukkan bahwa pelaksanaan demokrasi semakin baik. Tingginya tingkat partisipasi politik dimaksud, digambarkan dengan banyaknya rakyat yang mengikuti dan memahami masalah politik dan turut atau ingin melibatkan diri dalam berbagai kegiatan politik. Tinggi atau rendahnya suatu partisipasi merupakan sinyal dan indikator penting terhadap jalannya proses demokasi dan kedaulatan rakyat.

Peran serta atau partisipasi masyarakat dalam politik adalah kegiatan seseorang atau sekelompok orang untuk turut serta secara aktif dalam kehidupan politik, dengan jalan memilih pimpinan negara, dan secara langsung atau tidak langsung mempengaruhi kebijakan pemerintah (public policy). Secara konvensional kegiatan ini mencakup tindakan seperti: memberikan suara dalam pemilihan umum (voting); menghadiri rapat umum (campaign); menjadi anggota suatu partai atau kelompok kepentingan; mengadakan pendekatan atau hubungan (contacting) dengan pejabat pemerintah, atau anggota parlemen dan sebagainya. Dengan kata lain, partisipasi politik berarti keterlibatan individu-individu pada bermacam tingkatan di dalam sistem politik.

Komunikasi menjadi instrumen yang sangat penting dalam aktivitas politik. Trent \& Freidenberg menyebutkan; "Political election campaigns are campaign of communication and that the core of each campaign is communication", yang berarti kampanye pemilu politik ialah kampanye komunikasi dan bahwa inti dari setiap kampanye adalah komunikasi (dalam Cangara, 2016:239). 
Hasil penelitian nantinya dapat memastikan program-program dalam kampanye politik tidak dibangun atas postulat spekulatif, tetapi dibangun berlandaskan argumentasi rasional dengan proses yang dipercaya dan dapat dipertanggungjawabkan.

\subsection{Rumusan Masalah}

Sebagaimana uraian sebelumnya, penelitian ini berfokus untuk mengkaji:

1) Apakah terdapat pengaruh kampanye politik pasangan kandidat Mursil-Tengku Insyafuddin terhadap perilaku pemilih pada Pilkada Aceh Tamiang tahun 2017?

2) Apakah kampanye politik berpengaruh terhadap pengenalan figur pasangan kandidat?

3) Apakah kampanye politik memengaruhi pemahaman pemilih tentang partai politik yang mengusung pasangan kandidat ini?

4) Apakah kampanye politik memengaruhi pandangan atau sikap pemilih mengenai citra pasangan kandidat Mursil-Tengku Insyafuddin?

\subsection{Tujuan Penelitian}

Kajian ini dimaksudkan untuk memahami beberapa hal sebagai berikut, yakni:

1. Memahami pengaruh kampanye politik Mursil-Tengku Insyafuddin terhadap perilaku memilih pada Pilkada Aceh Tamiang 2017.

2. Menerangkan pengaruh kampanye politik terhadap pengenalan figur pasangan kandidat Mursil-Tengku Insyafuddin.

3. Menerangkan pengaruh kampanye politik terhadap pemahaman partai politik yang mengusung pasangan kandidat Mursil-Tengku Insyafuddin.

4. Menerangkan pengaruh kampanye politik terhadap sikap pemilih mengenai citra pasangan kandidat Mursil-Tengku Insyafuddin. 


\section{KERANGKA TEORI}

Komunikasi manusia memanfaatkan suatu simbol yang sangat berperan penting untuk dapat berkomunikasi. Simbol itu sendiri didefinisikan sebagai sesuatu yang dipergunakan untuk atau dipandang sebagai wakil sesuatu yang lainnya. Simbol tidaklah berdiri atau ada dengan sendirinya, simbol diciptakan dengan mempunyai tujuan yang hendak di informasikan kepada orang yang melihat simbol itu sendiri. Simbol merupakan petunjuk yang paling canggih, simbol ini terutama berfungsi dalam penalaran dan pemikiran, penggunaan simbol oleh manusia merupakan suatu prestasi yang telah diraih oleh manusia, sebab prestasi-prestasi manusia bergantung pada penggunaan simbol-simbol (Mulyana, 2015:96-107). Jadi simbol lebih merupakan tanda yang khusus bersifat arbitrer, artinya bersifat manasuka atau tidak sama dengan yang ditandai, dan hanya bisa dimengerti ataupun ditafsirkan dalam konteks tertentu oleh kelompok sosial tertentu pula, sehingga bersifat culture specific.

Tindakan simbolis hanya mungkin sebagai komunikasi antar manusia yang sangat sederhana, hubungan itu ditentukan dua orang, akan tetapi manusia sebagai makhluk sosial cenderung untuk berkelompok, hidup dalam suatu komunitas tertentu. Simbol-simbol semakin berkembang, semakin dipahami bersama melalui intraksi yang lebih luas, simbol pun bukan menjadi milik individu lagi, akan tetapi bersifat komuniter dan menjadi milik bersama dalam dunia sosial mereka.

\section{A. Komunikasi Massa}

Defisini komunikasi massa yang paling umum adalah cara penyampaian pesan yang sama, kepada sejumlah besar orang, dan dalam waktu yang serempak melalui media massa. Defenisi ini sebagaimana yang disampaikan Effendy (2006:20), komunikasi massa ialah komunikasi melalui media massa, dalam pada ini media massa mencakup pengertian komunikasi massa itu adalah surat kabar, majalah, radio, televisi, atau film. Jadi, media massa modern merupakan produk teknologi modern yang selalu berkembang menuju kesempurnaan. Tidak ada batasan media dalam penggunaan komunikasi massa ini, termasuk yang paling mutakhir komunikasi lewat media daring (online). Sedangkan menurut Gerbner, "Mass Comunication is the technologically and 
institutionally based production and distribution of the most broadly shared continuous flow of messages in industrial societies", menggambarkan bahwa komunikasi massa menghasilkan suatu produk berupa pesan-pesan komunikasi yang disebarkan dan didistribusikan kepada khayalak luas secara terus menerus dalam jarak waktu yang tetap (dalam Ardianto dan Komala, 2005:3-4).

Komunikasi massa disampaikan secara terbuka kepada masyarakat heterogen yang jangkauannya relatif besar. Komunikasi massa berperan sebagai cara yang efektif untuk menyampaikan informasi antara pihak yang ingin menyampaikan informasi, dengan pihak yang ingin diberikan informasi. Baik komunikasi bagi perorangan atau individu, komunikasi kelompok, maupun fungsi utamanya sebagai komunikasi bagi masyarakat luas.

Menurut McQuail (2010:235-262), terdapat ciri-ciri khusus komunikasi massa antara lain:

1) Memproduksi dan mendistribusikan "pengetahuan" dalam wujud informasi, pandangan dan budaya.

2) Menyediakan saluran untuk menghubungkan orang tertentu dengan orang lain dari pengirim ke penerima dan dari khalayak kepada anggota khalayak lainnya.

3) Media menyelenggarakan sebagian besar kegiatannya dalam lingkungan publik.

4) Partisipasi anggota khalayak dalam institusi pada hakekatnya bersifat sukarela, tanpa adanya keharusan atau kewajiban sosial.

5) Institusi media dikaitkan dengan industri pasar karena ketergantungannya pada imbalan kerja, teknologi dan kebutuhan pembiayaan.

6) Meskipun media itu sendiri tidak memiliki kekuasaan, namun institusi ini selalu berkaitan dengan kekuasaan negara karena adanya kesinambungan pemakaian media.

Lebih lanjut Nuruddin (2007:66-91) mengatakan, ada beberapa fungsi komunikasi massa, sebagai berikut. 
1) Fungsi Informasi. Fungsi informasi merupakan fungsi paling penting yang terdapat dalam komunikasi massa, komponen paling penting untuk mengetahui fungsi informasi ini adalah berita-berita yang disajikan. Iklan pun dalam beberapa hal memiliki fungsi memberikan informasi di samping fungsi-fungsi yang lain.

2) Fungsi Hiburan. Fungsi hiburan untuk media elektronik menduduki posisi yang paling tinggi dibandingkan dengan fungsi-fungsi yang lain. Masyarakat kita masih menjadikan televisi sebagai media hiburan. Dalam sebuah keluarga, televisi bisa menjadi perekat keintiman keluarga itu, karena masing-masing anggota mempunyai kesibukan sendirisendiri, misalnya suami dan istri kerja seharian sedangkan anak-anak sekolah. Setelah kelelahan dengan aktivitasnya masing-masing, ketika malam hari berada dirumah, kemungkinan besar mereka menjadikan televisi sebagai media hiburan sekaligus sarana untuk berkumpul keluarga.

3) Fungsi Persuasi. Fungsi persuasi komunikasi massa tidak kalah pentingnya dengan fungsi informasi dan hiburan. Banyak bentuk tulisan yang apabila diperhatikan sekilas hanya berupa informasi, tetapi jika diperhatikan secara lebih jeli ternyata terdapat fungsi persuasi. Tulisan pada tajuk rencana, artikel dan surat pembaca pada surat kabar, misalnya, merupakan contoh tulisan persuasif.

4) Fungsi Transmisi Budaya. Transmisi budaya merupakan fungsi komunikasi massa yang paling luas, meskipun paling sedikit dibicarakan, transmisi budaya tidak dapat dielakkan selalu hadir dalam bentuk komunikasi yang mempunyai dampak pada penerimaan individu. Melalui individu, komunikasi menjadi bagian dari pengalaman kolektif kelompok, publik, audiens berbagai jenis, dan individu dari suatu massa. 
5) Fungsi Kohesi Sosial. Kohesi yang dimaksud disini adalah penyatuan. Artinya, media massa mendorong masyarakat untuk bersatu. Dengan kata lain, media massa merangsang masyarakat untuk memikirkan dirinya bahwa bercerai-berai bukan keadaan yang baik bagi kehidupan mereka.

6) Fungsi Pengawasan. Bagi Laswell, komunikasi massa mempunyai fungsi pengawasan. Artinya, menujuk pada pengumpulan dan penyebaran informasi mengenai kejadiankejadian yang ada di sekitar kita. Fungsi pengawasan dibagi menjadi dua, yakni warning or beware surveillance atau pengawasan peringatan dan instrumental surveillance atau pengawasan instrumental.

7) Fungsi Korelasi. Fungsi korelasi yang dimaksud adalah fungsi yang menghubungkan bagian-bagian dari masyarakat agar sesuai dengan lingkungannya. Erat kaitannya dengan fungsi ini adalah peran media massa sebagai penghubung antara berbagai komponen masyarakat.

8) Fungsi Pewarisan Sosial. Dalam pada ini media massa berfungsi sebagai wahana pendidikan, baik yang menyangkut pendidikan formal maupun informal yang mencoba meneruskan atau mewariskan suatu ilmu pengetahuan, nilai, norma, pranata, dan etika dari satu generasi ke generasi selanjutnya.

9) Fungsi Melawan Kekuasaan dan Kekuatan Represif. Dalam kurun waktu yang panjang, komunikasi massa dipahami secara linier memerankan fungsi-fungsi klasik seperti yang diungkapkan sebelumnya. Hal yang dilupakan oleh banyak orang adalah bahwa kominikasi massa bisa menjadi sebuah alat untuk melawan kekuasaan dan kekuatan represif. Komunikasi massa berperan memberikan informasi, terutama yang menyangkut motif-motif tertentu untuk melawan kemapanan. 
10) Fungsi Menggugat Hubungan Trikotomi. Hubungan trikotomi adalah hubungan yang bertolak belakang antara tiga pihak. Dalam kajian komunikasi, hubungan trikotomi melibatkan pemerintah, media, dan masyarakat. Ketiga pihak ini dianggap tidak pernah mencapai sepakat kerana perbedaan kepentingan masing masing pihak.

\section{B. Kampanye Politik}

Dalam pertarungan politik, komunikasi merupakan hal yang sangat penting. Dalam komunikasi politik, media massa termasuk kedalam saluran utama menyampaikan pesan-pesan politik. pelbagai metode dan kegiatan komunikasi seperti pemberitaan, iklan, kampanye, propaganda, public relations, dan lain sebagainya dioptimalkan peran dan fungsinya. Pada pemilihan kepala daerah misalnya, setiap pasangan kandidat berserta tim kampanye mereka melakukan komunikasi dan berkampanye untuk meyakinkan para pemberi suara/konstituen, bahwa kelompok, partai politik, kandidat atau golongannya adalah calon-calon yang paling layak untuk menang dan terpilih. Dan saluran yang paling dominan digunakan untuk komunikasi politik mereka adalah komunikasi massa.

Halik (2017) menyebutkan, komunikasi politik merupakan aktivitas pendistribusian nilai-nilai dan penyampaian simbol-simbol politik. Bentuk hubungan antara komunikasi dan politik tampak pada penyajian makna bagi ide-ide politik, mendefinisikan kedudukan dan fungsi lembaga kekuasaan negara, dan mempromosikan citra kepemimpinan. Format dan substansi simbol-simbol politik tersebut juga variatif. Munculnya kecenderungan baru untuk melihat fenomena dan aktivitas komunikasi politik dari sudut pandang interpretif dan simbol non-bahasa menunjukkan semakin berkembangnya bidang komunikasi politik.

Pengkajian dan pemanfaatan komunikasi untuk kepentingan politik sebetulnya sudah lama berlangsung. Dalam dunia modern, Harold Lasswell menjadi salah seorang perintisnya lewat buku Propaganda Technique in the World War yang diterbitkan pada 1927. Buku The Stucture and Functions of Communication in Society dengan model who says what, to whom, in which channel, with what effect 
merupakan karya monumental Lasswell yang terus dikembangkan dalam buku-buku lainnya seperti yang ditulis pada tahun 1958, Politics: Who Gets What, When, How (Hikmat, 2014:114).

Perubahan besar dalam demokrasi di Indonesia -termasuk dalam konteks ruang politik lokalmembawa dampak signifikan terhadap strategi komunikasi politik yang ada. Para kontestan pada kontestasi pemilu lokal -baik pemilihan legislatif maupun pemilihan kepala daerah- mulai berpikir keras bagaimana caranya meyakinkan khalayak supaya mereka bersedia memberikan suara untuk para calon tersebut. Para kontestan dibantu oleh para analis dan pakar politik melakukan terobosan untuk menjual citra, ide, gagasan dan tujuan politiknya dalam suatu pengemasan melalui komunikasi pemasaran politik yang mengikuti polapola komunikasi pemasaran produk komersial pada umumnya.

Harris mendefinisikan komunikasi pemasaran politik sebagai suatu keinginan umum yang disamakan dengan teknik yang digunakan dalam upaya mengajak pemilih dalam kampanye untuk mempromosikan baik politisinya maupun kebijakannya (dalam Nurbasari, 2013). Komunikasi pemasaran politik adalah kombinasi dari kebijakan komunikasi politik dan komunikasi pemasaran dan untuk mempromosikan aktivitas politik dengan menggunakan model teknik pemasaran komersial sebagai mewakili seperangkat metode yang dapat digunakan oleh organisasi-organisasi politik untuk pencapaian tujuan dalam hal program politik atau dalam memengaruhi perilaku para pemilih dengan melakukan strategi tertentu.

Secara lebih spesifik, komunikasi pemasaran politik memang bertujuan akhir untuk memengaruhi sikap seseorang atau khalayak supaya mereka mau mengikuti “arahan” sebagaimana yang dilakukan dalam pemasaran tersebut. Attitude theory menyebutkan bahwa konsep sikap sangat berperan penting dalam menjelaskan tindakan manusia dengan memandang sikap sebagai disposisi behavorial (perilaku). Salah satu defenisi paling awal untuk sikap dikemukakan pada 1918 oleh William Thomas \& Florian Znaniecki (dalam Littlejohn \& Foss (ed), 2016: 67-68) yang mendefenisikannya sebagai keadaan kesiapan mental dan neural, yang diorganisasikan melalui pengalaman, memberi pengaruh dinamis pada respons individu terhadap semua objek dan situasi yang terkait dengan individu itu. 


\section{Kerangka Konseptual}

Kerangka berpikir dalam penelitian ini berangkat dari dugaan adanya pengaruh kampanye politik pasangan Mursil-Tengku Insyafuddin terhadap perilaku pemilih pada Pilkada Aceh Tamiang tahun 2017. Perilaku pemilih di sini digambarkan dalam tiga variabel, yakni; Pengenalan figur pasangan kandidat $\left(\mathrm{Y}_{1}\right)$; Pemahaman tentang partai politik pengusung pasangan kandidat $\left(\mathrm{Y}_{2}\right)$, serta Pandangan atau sikap pemilih mengenai citra pasangan kandidat $\left(\mathrm{Y}_{3}\right)$. Ketiga variabel tersebut menjadi variabel terikat pada penelitian ini. Ketiga variabel $\mathrm{Y}$ baik secara simultan dan terpisah akan diuji oleh variabel $\mathrm{X}$ untuk menemukan dugaan pengaruh kampanye terhadap perilaku pemilih.

Selanjutnya, dugaan pengaruh kampanye politik di atas dianalisis melalui frekuensi mengakses media kampanye $\left(\mathrm{X}_{1.1}\right)$, frekuensi mengakses profil kandidat $\left(\mathrm{X}_{1.2}\right)$, frekuensi menyaksikan penyampaian pesan-pesan politik pada kampanye $\left(\mathrm{X}_{1.3}\right)$, dengan pengenalan figur pasangan kandidat $\left(\mathrm{Y}_{1}\right)$. Pengaruh terhadap perilaku pemilih juga diukur dari pemahaman partai politik yang menjadi koalisi pengusung pasangan kandidat. Hal tersebut berangkat dari dugaan adanya pengaruh frekuensi mengakses media kampanye $\left(\mathrm{X}_{1.1}\right)$, frekuensi mengakses profil kandidat $\left(\mathrm{X}_{1.2}\right)$ dan frekuensi menyaksikan penyampaian pesan-pesan politik pada kampanye $\left(\mathrm{X}_{1.3}\right)$ serta Pengetahuan topik kampanye $\left(\mathrm{X}_{1.4}\right)$ dengan pemahaman tentang partai politik pengusung pasangan kandidat $\left(\mathrm{Y}_{2}\right)$.

Pengaruh kampanye politik terhadap perilaku pemilih juga dianalisis dari sikap citra pemilih terhadap pasangan kandidat. Variabel terikat ini diukur dari frekuensi mengakses media kampanye $\left(\mathrm{X}_{1.1}\right)$, frekuensi mengakses profil kandidat $\left(\mathrm{X}_{1.2}\right)$, frekuensi menyaksikan penyampaian pesan-pesan politik pada kampanye $\left(\mathrm{X}_{1.3}\right)$, pengetahuan topik kampanye $\left(\mathrm{X}_{1.4}\right)$, penilaian tampilan pesan pada media kampanye $\left(\mathrm{X}_{1.5}\right)$, penilaian isi atau muatan pesan pada media kampanye $\left(\mathrm{X}_{1.6}\right)$, dan penilaian penyampaian pesan politik pada kampanye tatap muka $\left(\mathrm{X}_{1.7}\right)$, serta penilaian isi pesan politik pada kampanye tatap muka $\left(\mathrm{X}_{1.8}\right)$ dengan pandangan atau sikap pemilih mengenai citra pasangan kandidat $\left(\mathrm{Y}_{3}\right)$.

Setelah menemukan dugaan pengaruh kampanye politik terhadap perilaku pemilih, selanjutnya dilakukan pengujian korelasi hubungan variabel $\mathrm{X}$ dan variabel $\mathrm{Y}$ secara simultan untuk mengetahui derajat 
keeratan hubungan antar variabel tersebut. Berdasarkan hal-hal yang telah diuraikan di atas, maka peneliti membentuk kerangka pemikiran sebagai berikut:

Gambar 2.1. Kerangka konseptual penelitian

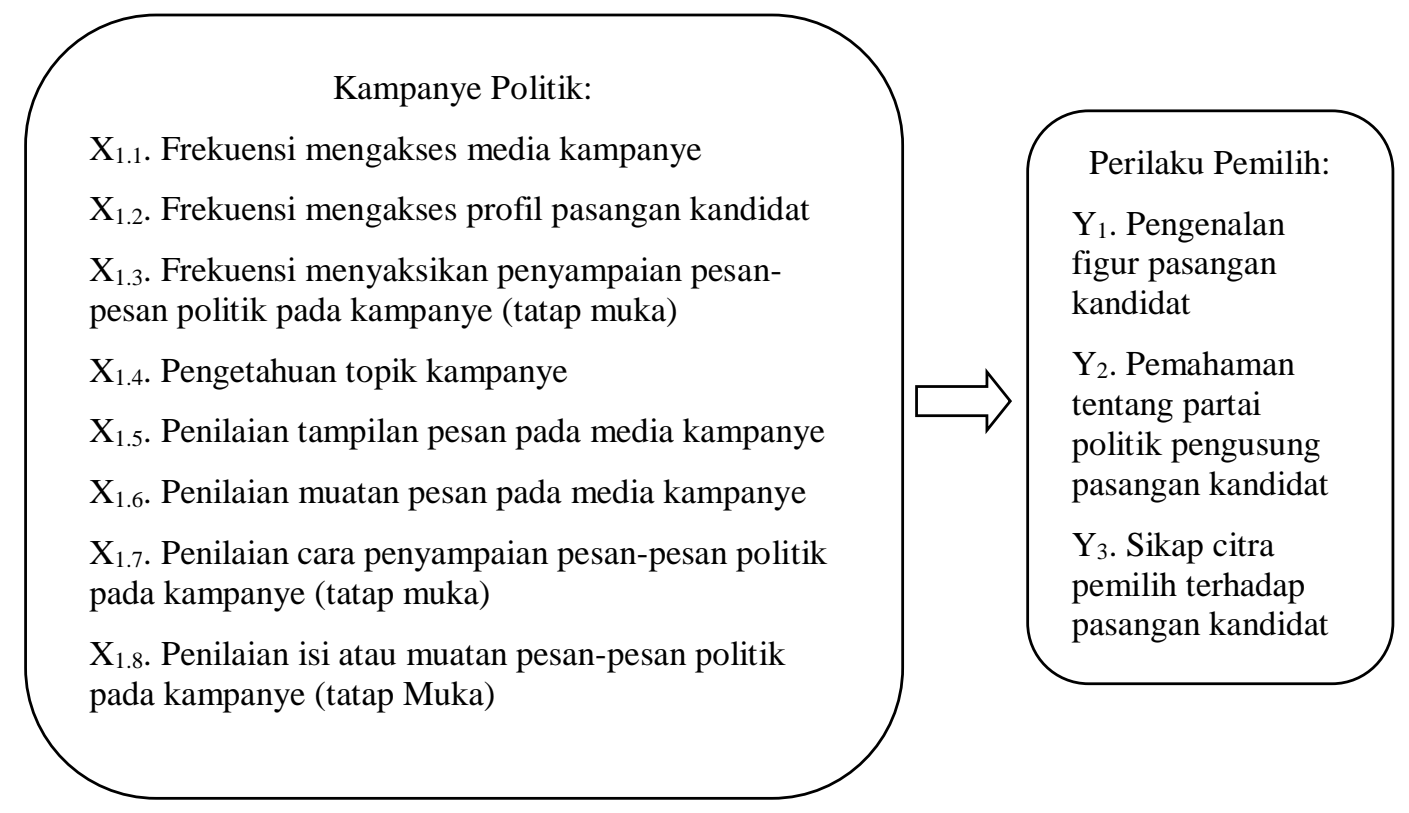

Sumber: Peneliti, 2017.

\subsection{Hipotesis}

Berdasarkan kerangka pemikiran yang didapat dari tinjauan teoretis, maka diajukan beberapa hipotesis pada penelitian ini, sebagai berikut:

1. $\mathrm{H}_{0}$ : Tidak terdapat pengaruh kampanye politik terhadap perilaku pemilih.

$\mathrm{H}_{\mathrm{a}}$ : Terdapat pengaruh kampanye politik terhadap perilaku pemilih.

2. $\mathrm{H}_{0}$ : Tidak terdapat pengaruh kampanye politik terhadap pengenalan figur pasangan kandidat.

$\mathrm{H}_{\mathrm{a}}$ : Terdapat pengaruh kampanye politik terhadap pengenalan figur pasangan kandidat.

3. $\mathrm{H}_{0}$ : Tidak terdapat pengaruh kampanye politik terhadap pemahaman pemilih tentang partai politik yang menjadi pengusung pasangan kandidat. 
$\mathrm{H}_{\mathrm{a}}$ : Terdapat pengaruh kampanye politik terhadap pemahaman pemilih tentang partai politik yang menjadi pengusung pasangan kandidat, dan

4. $\mathrm{H}_{0}$ : Tidak terdapat pengaruh kampanye politik terhadap pandangan atau sikap pemilih mengenai citra pasangan kandidat.

$\mathrm{H}_{\mathrm{a}}$ : Terdapat pengaruh kampanye politik terhadap sikap pemilih mengenai citra pasangan kandidat.

\section{METODOLOGI}

Pada penelitian ini, ada dua konsep yang dipergunakan, yakni kampanye politik dan perilaku pemilih. Kampanye politik diperlakukan sebagai variabel bebas, dan perilaku pemilih dijadikan sebagai variabel terikat. sedangkan karakteristik responden hanya sebagai faktor anteseden dan berfungsi sebagai pelengkap. Sementara, definisi operasional merupakan penjabaran lebih lanjut dari konsep yang telah dikelompokkan dalam kerangka konsep tadi. Definisi operasional merupakan suatu informasi ilmiah yang sangat membantu peneliti lain yang ingin menggunakan variabel yang sama.

\section{Skala Pengukuran}

Skala yang digunakan adalah skala nominal dan skala ordinal model Likert. Skala nominal adalah skala yang paling sederhana. Bilangan atau angka hanya sebagai simbol yang menandai suatu objek untuk membedakan dengan objek lainnya (Kriyantono, 2014:136). Hasil penilaian skala nominal nantinya akan dianalisis dengan perangkat uji tabulasi silang dan dijabarkan secara deskriptif tentang pilihan-pilihan responden atas pertanyaan-pertanyaan yang telah diajukan.

Sedangkan skala Likert digunakan untuk mengukur sikap seseorang tentang sesuatu objek sikap (Kriyantono, 2014:138). Indikator-indikator pada skala Likert memiliki nilai tertentu yang dapat diakumulasikan serta digunakan untuk menguji hipotesis penelitian yang telah diajukan. 
Pertanyaan-pertanyaan dalam kuesioner penelitian yang dijawab oleh para responden memiliki pilihan dan nilai sebagaimana tertera berikut ini.

Apabila hasil pengujian menunjukkan :

1. Jika $F_{\text {hitung }}>F_{\text {tabel }}$ maka $\mathrm{H}_{0}$ ditolak dan $\mathrm{H}_{\mathrm{a}}$ diterima. Artinya variabel bebas secara simultan berpengaruh terhadap variabel terikat.

2. Jika $F_{\text {hitung }}<\mathrm{F}_{\text {tabel }}$ maka $\mathrm{H}_{\mathrm{a}}$ ditolak dan $\mathrm{H}_{0}$ diterima. Artinya variabel bebas secara simultan tidak berpengaruh terhadap variabel terikat. Hasil pengujian dipaparkan berikut ini.

3. Jika nilai signifikansi $<0,05$ maka variabel bebas secara simultan berpengaruh signifikan terhadap variabel terikat.

4. Jika nilai signifikansi $>0,05$ maka variabel bebas secara simultan tidak berpengaruh signifikan terhadap variabel terikat.

Selanjutnya, pada pengujian utama variabel $\mathrm{X}$ dan $\mathrm{Y}$ dilanjutkan dengan mengukur tingkat keeratan hubungan antar variabel tersebut dengan rumus statistik korelasi rank-order (Spearman's Rho Rank-Order Correlation).

\section{Kerawanan Pilkada}

Dinamika masa kampanye pilkada jika disaksikan secara langsung sebenarnya tak kalah menarik dengan apa yang terjadi pada masa kampanye pemilihan presiden. Perbedaan yang paling jelas hanya ada pada luasan cakupan kegiatan, yang satu lokal dan satunya lagi nasional. Namun, keduanya kerap memancing antusiasme masyarakat. Sebagian bahkan ekstrem, hingga memicu kekerasan antar tim kampanye atau pendukung pasangan kandidat.

Di Aceh, tiap kali gelaran pilkada dilaksanakan maka isu-isu kekerasan selalu merebak. Ancaman kerap menjadi jualan sebagian oknum untuk memenangkan calon tertentu. Karenanya, kerawananan pemilihan umum menjadi substansi penting untuk diperhatikan. Hal ini didasarkan 
pada angka Indeks Kerawanan Pemilu (IKP) yang dikeluarkan oleh Badan Pengawas Pemilihan Umum (Bawaslu) Republik Indonesia.

Dari tujuh provinsi yang melaksanakan pilkada pada tahun 2017, Aceh mendapat peringkat kedua pada indeks tersebut, dengan total nilai 3,32. Angka indeks ini didapat setelah mengakumulasi semua dimensi penilaian, yakni penyelenggaraan, kontestasi, dan partisipasi. Untuk lebih jelas, kategori nilai indeks kerawanan pemilu dapat dilihat pada tabel berikut ini.

Tabel. Kategori skor Indeks Kerawanan Pemilu

\begin{tabular}{|c|c|c|}
\hline Skor & Kategori & Keterangan \\
\hline $0-1,99$ & $\begin{array}{l}\text { Kerawanan } \\
\text { Rendah }\end{array}$ & $\begin{array}{l}\text { Indikasi kerawanan relatif kecil, cenderung tidak } \\
\text { rawan. }\end{array}$ \\
\hline $2,0-2,99$ & $\begin{array}{c}\text { Kerawanan } \\
\text { Sedang }\end{array}$ & $\begin{array}{l}\text { Ada indikasi potensi kerawanan yang cukup } \\
\text { signifikan, sehingga perlu diperhatikan dan } \\
\text { diantisipasi. }\end{array}$ \\
\hline $3,0-5,0$ & $\begin{array}{c}\text { Kerawanan } \\
\text { Tinggi }\end{array}$ & $\begin{array}{l}\text { Ada indikasi potensi kerawanan yang signifikan } \\
\text { yang perlu diperhatikan, diantisipasi, serta } \\
\text { diambil langkah-langkah untuk meminimalisir } \\
\text { kerawanan. }\end{array}$ \\
\hline
\end{tabular}

Sumber: Bawaslu RI, 2017 (data diolah).

Namun demikian, penilaian terhadap Provinsi Aceh berbanding terbalik dengan Indeks Kerawanan Pemilu Kabupaten Aceh Tamiang. dari hasil penilaian Bawaslu RI, Kabupaten Aceh Tamiang memiliki nilai indeks kerawanan pemilu yang rendah, yakni hanya 1,96. Kabupaten Aceh Tamiang berada di urutan ke 45 dari 94 kabupaten/kota yang melaksanakan pilkada pada tahun 2017. Ini dapat dimaknai menebar ancaman yang menimbulkan ketakutan akan kembalinya bayang-bayang konflik bersenjata tidak berlaku di Aceh Tamiang.

Padahal di kabupaten lain di Aceh, ancaman yang sama kerap menjadi “jualan" kampanye calon atau pasangan kandidat dari partai politik tertentu. Berkaitan dengan ini pula, dalam konteks 
penelitian ini, maka faktor ketakutan akibat ancaman dan/ atau yang disertai kekerasan tidak menjadi faktor dominan dalam kampanye politik yang dilaksanakan oleh tiap pasangan kandidat.

Hal ini pernah diungkapkan oleh Ningsih (2014) pada penelitiannya yang menyoroti kualitas demokrasi di Aceh Tamiang. Dalam pada ini, Ningsih menyampaikan bahwa ancaman dan intimidasi supaya memilih pasangan kandidat dari partai tertentu memang terjadi, dan biasanya di daerah pinggiran atau pedalaman. Intimidasi atau ancaman lisan yang dilontarkan selalu mengarah kepada bayangan akan kembalinya "periode kelam" di Aceh, dan tidak terjaminnya keselamatan diri dan keluarga si pemilih bila tidak memilih dan memenangkan pasangan kandidat dari partai tertentu.

Namun demikian, hasil penelitian Ningsih (2014) di atas menyebutkan pula walau ini hal itu nyata adanya, tapi ancaman atau intimidasi yang terjadi tidak signifikan dan tidak memiliki pengaruh yang nyata di Kabupaten Aceh Tamiang. Dari dua kali perhelatan pilkada yang digelar di Aceh Tamiang -pilkada tahun 2007 dan tahun 2012- berdasarkan fakta yang ada pelaksanaan kedua pilkada tersebut telah berjalan dengan baik, transparan, kompetitif serta berlangsung dengan suasana yang relatif kondusif dan damai. Keadaan ini tentunya dapat diciptakan karena adanya kerjasama dari pelbagai pihak yang turut serta di dalam menjaga keberhasilan penyelenggaraan pilkada di kabupaten Aceh Tamiang.

\section{Perolehan Suara}

Pilkada Aceh Tamiang 2017 diikuti oleh lima pasangan calon bupati-wakil bupati. Dari total lima pasangan calon ini, tiga pasang calon diusung oleh koalisi partai politik, dan dua pasangan calon lainnya terdaftar sebagai pasangan calon perseorangan. Lima pasangan calon ini secara berurut adalah sebagai berikut: 1) Ir. Rusman-M. Ichsan; 2) Hamdan Sati, ST-Izwardi, S.IP; 3) Mursil-Tengku Insyafuddin ; 4) Drs. Iskandar Zulkarnain, MAP-Drs. Ahmad As'adi; dan 5) 
Lukmanul Hakim-Abdul Manaf. Berikut dipaparkan perolehan suara pada Pilkada Aceh Tamiang 2017.

Tabel. Jumlah perolehan suara pada Pilkada Aceh Tamiang 2017

\begin{tabular}{|c|c|c|c|c|c|c|}
\hline \multirow{2}{*}{ No } & \multirow{2}{*}{ Kecamatan } & \multicolumn{5}{|c|}{ Nomor Pasangan Kandidat } \\
\hline & & 1 & 2 & 3 & 4 & 5 \\
\hline 1 & Banda Mulia & 2.097 & 1.551 & 1.131 & 178 & 345 \\
\hline 2 & Bandar Pusaka & 1.641 & 1.456 & 1.806 & 221 & 484 \\
\hline 3 & Bendahara & 2.597 & 2.848 & 2.225 & 1.103 & 692 \\
\hline 4 & Karang Baru & 4.459 & 3.860 & 6.306 & 1.081 & 2.799 \\
\hline 5 & Kejuruan Muda & 3.338 & 3.890 & 5.289 & 488 & 1.692 \\
\hline 6 & Kota Kuala Simpang & 1.907 & 1.563 & 2.981 & 311 & 889 \\
\hline 7 & Manyak Payed & 3.857 & 3.883 & 4.035 & 892 & 594 \\
\hline 8 & Rantau & 3.531 & 3.907 & 5.752 & 554 & 1.770 \\
\hline 9 & Sekerak & 1.077 & 558 & 1.220 & 148 & 306 \\
\hline 10 & Seruway & 2.229 & 4.526 & 4.549 & 549 & 484 \\
\hline 11 & Tamiang Hulu & 1.660 & 3.271 & 2.719 & 319 & 481 \\
\hline 12 & Tenggulun & 1.290 & 1.824 & 1.594 & 207 & 2.549 \\
\hline & Jumlah Total & 29.683 & 33.137 & 39.607 & 6.051 & 13.085 \\
\hline
\end{tabular}

Sumber: KIP Aceh Tamiang, 2017 (data diolah).

Hal menarik dari perhelatan kontestasi pilkada di Aceh Tamiang, bahwa dari tiga kali penyelenggaraan pilkada, belum pernah ada pasangan kandidat petahana (incumbent) yang berhasil memenangkan suara rakyat untuk kembali menjadi kepala daerah untuk kali kedua. Pasangan kandidat yang akhirnya terpilih berasal dari penantang pada pilkada sebelumnya, atau pendatang baru. Ini menjadi alasan kuat mengapa penelitian tentang analisis evaluasi kampanye politik dan perilaku memilih layak dilakukan di Aceh Tamiang.

Sebagaimana telah disebutkan pada bagian sebelumnya, penelitian dilakukan pada tiga kecamatan, yakni Kecamatan Manyak payed, Kecamatan Karang Baru, dan Kecamatan Kuala Simpang. Pemilihan tiga kecamatan ini didasarkan pada jumlah perolehan suara tertinggi, dan pertimbangan heterogenitas demografis masyarakat yang ada. Dari sini diharapkan bahwa hasil 
analisis dapat digeneralisasi pada semua wilayah Aceh Tamiang. Analisis pengaruh kampanye politik dan perilaku memilih akan memberikan penjelasan terhadap kampanye politik dan perilaku memilih pada Pilkada Aceh Tamiang 2017. Hasil analisis nantinya diharapkan dapat menjadi masukan berharga kepada dunia akademik, terlebih bagi para praktisi politik lokal di Aceh Tamiang.

\section{HASIL}

Aceh Tamiang dari sejak terbentuknya telah melaksanakan pemilihan kepala daerah sebanyak tiga kali. Kali pertama dilaksanakan pada 2006. Pemilihan kepala daerah masa itu digelar sebanyak dua putaran. Pada putaran kedua pelaksanaan pilkada pertama, terpilihlah pasangan Drs. Abdul Latief-Awaluddin, SH, Sp.N, MH sebagai Bupati-Wakil Bupati Aceh Tamiang periode 2007-2012.

Pada tahun 2012, Aceh Tamiang kembali melaksanakan pilkada, yang juga digelar dua putaran. Hasilnya, terpilihlah Hamdan Sati, ST-Drs. Iskandar Zulkarnaen, MAP sebagai BupatiWakil Bupati Aceh Tamiang periode 2012-2017. Pada pilkada kedua, hasil keputusan bupati terpilih ditetapkan setelah melewati sidang persengketaan hasil pemilu di Mahkamah Konstitusi. Pasangan Bupati-Wakil Bupati terpilih akhirnya dilantik jelang akhir tahun 2012, yaitu tanggal 28 Desember 2012.

Pelaksanaan pemilihan kepala dan wakil kepala daerah kali ketiga ini diatur dalam UndangUndang Nomor 1 Tahun 2015 Tentang Penetapan Peraturan Pemerintah Pengganti Undang Undang Nomor 1Tahun 2014 Tentang Pemilihan Gubernur, Bupati, dan walikota Menjadi Undang Undang. Dalam pada ini, pemerintah juga menetapkan perhelatan akbar ini dilaksanakan secara serentak. Pada pelaksanaan pilkada serentak tahun 2017 ini, total ada 101 daerah sebagai 
pelaksana. Terdiri dari 7 Provinsi, 18 Kota, dan 76 Kabupaten, di mana Kabupaten Aceh Tamiang adalah satu kabupaten yang melaksanakan perhelatan akbar demokrasi tersebut.

\section{Temuan pada Variabel Kampanye Politik}

\section{1) Jenis Media Kampanye yang Diketahui}

Analisis tabulasi tabel tunggal menunjukkan jawaban responden bahwa mereka sangat mengenal baliho sebagai media yang digunakan berkampanye pada Pilkada Aceh Tamiang 2017. Pengetahuan tentang baliho menempati urutan pertama pada pertanyaan jenis media yang diketahui dengan persentase sebesar $86,8 \%$. Kemudian, $61,8 \%$ responden mengetahui poster sebagai jenis media kampanye. Selanjutnya, 22,3\% responden mengetahui bahwa iklan media cetak merupakan satu dari media kampanye.

Ada 4,8\% responden yang mengetahui media kampanye berupa iklan radio. Sedangkan 15,8\% memilih jawaban lainnya. Ketika peneliti menanyakan, maka mayoritas responden yang memilih jawaban lainnya mengatakan kalender sebagai media kampanye yang mereka ketahui. Pengetahuan responden tentang media kampanye Pilkada Aceh Tamiang 2017 disajikan pada tabel berikut.

\section{2) Pengetahuan tentang Jenis Media yang Digunakan Kandidat Berkampanye}

Sebagaimana jawaban responden pada butir pertanyaan sebelumnya, di butir pertanyaan ini pun responden menjawab dengan hasil jawaban yang tidak banyak berubah. Pada butir pertanyaan ini, responden tetap memilih baliho sebagai pengetahuan mereka akan media yang digunakan berkampanye oleh pasangan kandidat. Pengetahuan tentang baliho ini mendapat porsi sebesar $85,5 \%$. Selanjutnya, poster tetap menempati urutan kedua dengan $62 \%$, iklan media cetak sebesar $14,5 \%$, iklan radio hanya diketahui oleh $5 \%$ responden dan yang menjawab lainnya sebesar 
17,5\%, dengan mayoritas menuliskan kalender sebagai media kampanye yang mereka dapatkan. Pengetahuan tentang jenis media yang digunakan kandidat berkampanye digambarkan pada tabel sebagai berikut.

\section{3) Jenis Media Kampanye yang Pernah Dibaca}

Ketika menjawab butir pertanyaan ini, responden penelitian tetap menempatkan pilihan bahwa baliho adalah media kampanye yang paling sering dibaca. Persentase poster sebagai media kampanye yang paling sering dibaca sebesar $82,3 \% .65,5 \%$ responden menjawab poster sebagai media yang paling sering dilihat/dibaca. Iklan media cetak mendapat angka sebesar $18 \%$. Kampanye melalui iklan radio pernah didengarkan oleh $4.8 \%$ responden. Sementara selebihnya, yakni $15,5 \%$ responden memilih lainnya sebagai jawaban butir pertanyaan ini. Hasil analisis tabel tunggal butir pertanyaan jenis media kampanye yang pernah dilihat/dibaca disajikan pada tabel 4.11. berikut ini.

\section{4) Sumber Perolehan Informasi Kampanye}

Hasil analisis tabel tunggal pada butir pertanyaan ini menunjukkan bahwa baliho masih menjadi pilihan utama responden untuk mendapatkan informasi kampanye yang dilaksanakan kandidat atau tim kampanyenya. Baliho dipilih oleh 73,3\% responden. Poster menjadi pilihan kedua dengan besaran persentase $68 \%$. Iklan media cetak menjadi pilihan ketiga responden dengan

persentase $27 \%$. Iklan radio menjadi pilihan sebagian kecil responden, yakni $7 \%$. Sementara 19,3\% responden menjawab media lainnya sebagai sumber perolehan informasi kampanye kandidat.

\section{5) Pengetahuan tentang Kegiatan Kampanye}


Butir pertanyaan ini menanyakan seberapa besar pengetahuan mereka perihal kegiatan kampanye politik dalam agenda pemenangan pilkada pasangan kandidat Mursil-Tengku Insyafuddin. Hasilnya adalah mayoritas responden mengetahui pertemuan massal atau rapat umum menjadi bagian penting dari kegiatan kampanye yang dilakukan. Sebanyak 66,3\% responden menjawab pertemuan massal. Setelahnya, 58\% responden menjawab pertemuan pertemuan kelompok. Sebanyak 25,8\% responden mengetahui adanya kegiatan kampanye dari pintu ke pintu yang dilaksanakan oleh tim kampanye pasangan kandidat.

Ada $13,5 \%$ responden yang mengetahui adanya kegiatan safari shubuh sebagai bagian dari strategi kampanye. Selanjutnya, 9,8\% responden yang mengetahui kegiatan lain di luar dari empat kegiatan utama kampanye yang telah dilaksanakan kemarin. Sebaran jawaban butir pertanyaan ini dapat dilihat pada tabel 4.13. berikut ini.

\section{6) Mengikuti Kegiatan Kampanye Politik}

Hasil analisis butir pertanyaan ini dipaparkan sebagai berikut. Ada 55,3\% responden yang mengaku mengikuti kegiatan pertemuan kelompok. Sebanyak 49,8\% responden menjawab mengikuti kegiatan pertemuan massal atau rapat umum. Para responden mengaku juga mengikuti kegiatan lain yang tidak tertera pada pilihan jawaban. Persentase jawaban ini sebanyak 30,3\%. Ketika ditanyakan akan hal ini, para responden menjawab bahwa mereka pernah mengikuti kegiatan pelatihan kewirausahaan dan pelatihan kepemimpinan yang pernah dilaksanakan oleh tim kampanye pasangan kandidat. Ada 20,3\% responden yang pernah dikunjungi oleh tim kampanye yang bergerak dari pintu ke pintu.

Dari semua pilihan jawaban yang ada, responden yang pernah mengikuti kegiatan safari shubuh dalam rangkaian agenda kampanye pasangan kandidat Mursil-Tengku Insyafuddin, 
berjumlah $13 \%$ dari total responden. untuk lebih jelas, persentase pilihan jawaban responden pada butir pertanyaan di atas, disajikan pada tabel 4.14. sebagai berikut.

\section{7) Ketertarikan terhadap Topik Kampanye}

Ketertarikan responden tentang topik kampanye yang diangkat oleh pasangan kandidat Mursil-Tengku Insyafuddin. Ketertarikan responden terhadap topik kampanye sangat beragam. Namun, persentase jawaban terbesar yang dipilih oleh responden ialah topik pertanian sebanyak 57,5\%. Topik pendidikan dan topik agama menempati urutan berikutnya dengan persentase sebanyak 55,5\% dan 52\%. Topik pelayanan kesehatan dan rumah sakit menempati urutan keempat dengan persentase 50,5\%. Topik pemberdayaan ekonomi dan kemiskinan dipilih oleh 21,8\% responden yang ada. Selanjutnya, 18,8\% responden memilih pelayanan birokrasi dan korupsi sebagai topik yang menarik bagi mereka.

\section{Temuan pada Variabel Perilaku Memilih}

Pada variabel perilaku memilih, peneliti memberikan lima butir pertanyaan yang dianggap dapat mewakili bagaimana gambaran perilaku memilih pada Pilkada Aceh Tamiang tahun 2017.

\section{1) Akses Mengenal Pasangan Kandidat}

Sumber perolehan informasi atau akses untuk mengenal pasangan kandidat Mursil-Tengku Insyafuddin dapat dipastikan bahwa media kampanye menjadi sumber informasi atau akses pengenalan yang dominan. Para responden mayoritas memilih jawaban ini dengan persentase 45,5\%. Kemudian, tim sukses kampanye menjadi pilihan kedua responden dengan 31,8\%. Sebanyak 31,3\% responden mengaku teman atau keluarga mereka juga menjadi akses untuk mengenal pasangan kandidat. Lingkungan sosial menjadi pilihan keempat sebagai akses untuk 
mengenal pasangan kandidat dengan persentase sebesar 30,8\%. Dan ada 6,3\% responden menjawab lainnya, sebagai sumber mengenal pasangan kandidat.

\section{2) Pengetahuan Partai Politik Pengusung Pasangan Kandidat}

Pengetahuan responden tentang partai politik yang mengusung pasangan kandidat, dapat disimak jawaban responden atas butir pertanyaan ini, hanya 5,3\% responden yang menjawab sangat mengetahui partai politik pengusung pasangan kandidat. kemudian, 4\% responden mengaku mengetahui partai politik pengusung pasangan kandidat ini. Sementara, jawaban atas pertanyaan di atas didominasi oleh pilihan cukup tahu, yakni sebesar $40 \%$. Selanjutnya ada $38,2 \%$ responden menjawab bahwa mereka kurang mengetahui partai politik pengusung pasangan kandidat Mursil-Tengku Insyafuddin. Sebanyak 12,5\% responden menjawab mereka tidak mengetahui partai politik apa yang menjadi kendaraan bagi pasangan kandidat tersebut di atas.

\section{3) Penggunaan Sumber Informasi Lain}

Pertanyaan selanjutnya ialah, apakah para responden pernah menggunakan sumber informasi lain untuk mengetahui profil pasangan kandidat Mursil-Tengku Insyafuddin. Bahwa mayoritas responden memilih tokoh masyarakat sebagai sumber informasi lain yang pernah mereka akses untuk mengenal pasangan kandidat ini. Pilihan terhadap tokoh masyarakat ini separuh, atau sebesar 54,3\% dipilih oleh para responden. Selanjutnya, 40,8\% responden mengaku kalau mereka juga menggunakan sumber lain berupa pimpinan partai politik untuk mengetahui informasi profil pasangan kandidat Mursil-Tengku Insyafuddin.

Kemudian, 13,5\% responden menjawab bahwa kolega dan keluarga mereka menjadi akses lain yang pernah mereka gunakan sebagai sumber informasi. Ada 18,3\% responden menjawab bila mereka menjadikan ulama dan cendikiawan yang ada sebagai sumber informasi 
tambahan bagi mereka. Terakhir, 9,3\% responden yang menjadikan anggota legislatif sebagai sumber rujukan lain.

\section{4) Alasan Menyukai Pasangan Kandidat}

Pertanyaan ini dimaksudkan untuk mengetahui faktor apa saja yang menjadikan para responden menyukai pasangan kandidat ini. Alasan menyukai pasangan kandidat terpolarisasi menjadi tujuh butir jawaban. Persentase jawaban terbesar yang dipilih oleh para responden penelitian ialah faktor kepribadian calon adalah jawaban berikut yang dipilih para responden dengan persentase sebesar 32,8\%. Faktor visi, misi, dan rekam jejak pasangan kandidat menempati urutan kedua terbanyak dipilih oleh responden dengan $29,5 \%$. Selanjutnya, 27,3\% responden mengakui bahwa faktor etnis menjadi alasan mereka menyukai pasangan kandidat.

Faktor kekerabatan dan pertemanan dipilih oleh 19,3\% responden penelitian. Kemudian, faktor partai politik pengusung menempati urutan berikutnya dengan perolehan persentase $19 \%$. Faktor tim sukses kampanye dan media kampanye menjadi pilihan berikutnya oleh para responden. Faktor ini mendapat porsi sebesar 17,8\%. Ada 9,8\% responden menjadikan faktor selain dari pada yang disebutkan di atas sebagai alasan mereka menyukai pasangan kandidat.

\section{5) Topik Kampanye Politik yang Paling Diingat}

Pertanyaan lanjutan pada variabel perilaku memilih ialah berupa pertanyaan perihal topik atau isu kampanye politik yang paling diingat oleh para responden. Perihal topik atau isu kampanye politik pasangan kandidat Mursil-Tengku Insyafuddin yang paling diingat oleh para responden ialah topik pertanian dan agama. Topik kampanye politik tentang pertanian dan agama ini mendapat porsi pilihan terbesar dengan persentase masing-masing 53,3\% dan 52,8. Topik pendidikan menempati pilihan ketiga oleh para responden dengan besaran 50,8\%. Selanjutnya, topik pelayanan kesehatan dan rumah sakit menempati peringkat keempat pilihan para responden 
dengan persentase sebesar 42,5\%. Topik pemberdayaan ekonomi dan kemiskinan ada dipilihan kelima dengan besaran persentase $28,3 \%$. Topik pelayanan birokrasi dan korupsi dipilih oleh $15,5 \%$ responden sebagai topik kampanye yang paling mereka ingat.

\section{6) Karakter Pasangan Kandidat yang Paling Diingat}

Pertanyaan ini juga ditanyakan untuk menguji kembali seperti apa penilaian akan karakter pasangan kandidat Mursil-Tengku Insyafuddin yang pernah mereka temui. Mayoritas responden mengingat karakter jujur sebagai karakter pasangan kandidat yang paling mereka ingat. Karakter ini dipilih oleh para responden dengan persentase sebesar 42,8\%. Kemudian, karakter merakyat menempati persentase terbesar kedua dengan jumlah perolehan sebesar 38\%. Karakter agamis menjadi pilihan berikutnya dengan 36,3\% reponden memilih jawaban ini. Karakter cerdas dipilih oleh $31 \%$ responden dan karakter kharismatik sebanyak 15\% responden.

\section{7) Pasangan Kandidat yang Dipilih pada Pilkada}

Pertanyaan terakhir dari variabel ini ialah, pasangan kandidat bupati-wakil bupati yang dipilih para responden pada perhelatan pilkada serentak 2017 ini. Pasangan kandidat MursilTengku Insyafuddin menempati urutan pertama dengan perolehan pesentase 79,3\%. Pasangan kandidat Hamdan Sati, ST-Izwardi, SIP di urutan kedua dengan 11,7\%. Selanjutnya, pasangan kandidat Ir. Rusman-M. Ichsan memperoleh persentase 4,7\%. Pasangan kandidat Luqmanul Hakim-Abdul Manaf dipilih oleh 2,8\% responden dan, pasangan kandidat Drs. Iskandar Zulkarnain, MAP-Drs. Ahmad As'adi dipilih oleh 1,5\% responden yang terlibat dalam penelitian ini. 


\section{Analisis Pengaruh Kampanye Politik terhadap Perilaku Pemilih}

Pengujian hipotesis pertama dalam penelitian ini ialah menganalisis pengaruh kampanye politik terhadap perilaku pemilih. Dalam analisis utama kajian ini dilakukan dua pengujian, yakni 1) Menguji pengaruh kampanye politik terhadap perilaku pemilih, dan 2) Menguji koefisien korelasi untuk menemukan keeratan hubungan antara variabel $\mathrm{X}$ dan variabel $\mathrm{Y}$. Untuk menemukan dugaan pengaruh kampanye politik terhadap perilaku pemilih, pengujian menggunakan analisis regresi berganda dengan bantuan piranti software SPSS 24.0 for windows. Hasil pengujian disajikan pada tabel 4.23 berikut ini.

Dari hasil uji dapat diketahui tingkat kekuatan hubungan, arah hubungan, dan signifikansi hubungan antara variabel kampanye politik dan variabel perilaku pemilih. Secara terperinci dipaparkan sebagai berikut:

1. Hubungan variabel pengetahuan topik kampanye politik dengan variabel perilaku pemilih memiliki korelasi rendah; tingkat kekuatan hubungan yang pasti tetapi lemah. Angka koefisien korelasi bernilai positif sehingga hubungan kedua variabel tersebut bersifat searah (jenis hubungan searah). Karena nilai sig. (2-tailed) hasil perhitungan 0,000 $<0,01$ maka artinya ada hubungan yang signifikan (berarti) antar variabel ini.

2. Hubungan variabel frekuensi mengakses media kampanye politik dengan variabel perilaku pemilih memiliki korelasi sedang; tingkat kekuatan hubungan cukup kuat. Angka koefisien korelasi bernilai positif sehingga hubungan kedua variabel tersebut bersifat searah (jenis hubungan searah). Karena nilai sig. (2-tailed) hasil perhitungan 0,000 <0,01 maka artinya ada hubungan yang signifikan (berarti) antar variabel ini.

3. Hubungan variabel frekuensi mengakses informasi kandidat dengan variabel perilaku pemilih memiliki korelasi sedang; tingkat kekuatan hubungan cukup kuat. Angka koefisien 
korelasi bernilai positif sehingga hubungan kedua variabel tersebut bersifat searah (jenis hubungan searah). Karena nilai sig. (2-tailed) hasil perhitungan 0,000 $<0,01$ maka artinya ada hubungan yang signifikan (berarti) antar variabel ini.

4. Hubungan variabel frekuensi menyaksikan penyampaian pesan politik dengan perilaku pemilih memiliki korelasi sedang; tingkat kekuatan hubungan cukup kuat. Angka koefisien korelasi bernilai positif sehingga hubungan kedua variabel tersebut bersifat searah (jenis hubungan searah). Karena nilai sig. (2-tailed) hasil perhitungan 0,000 $<0,01$ maka artinya ada hubungan yang signifikan (berarti) antar variabel ini.

5. Hubungan variabel penilaian tampilan pesan pada media kampanye politik dengan perilaku pemilih memiliki korelasi rendah; tingkat kekuatan hubungan yang pasti tetapi lemah. Angka koefisien korelasi bernilai positif sehingga hubungan kedua variabel tersebut bersifat searah (jenis hubungan searah). Karena nilai sig. (2-tailed) hasil perhitungan 0,000 $<0,01$ maka artinya ada hubungan yang signifikan (berarti) antar variabel ini.

6. Hubungan variabel penilaian muatan pesan pada media kampanye politik dengan perilaku pemilih memiliki korelasi rendah; tingkat kekuatan hubungan yang pasti tetapi lemah. Angka koefisien korelasi bernilai positif sehingga hubungan kedua variabel tersebut bersifat searah (jenis hubungan searah). Karena nilai sig. (2-tailed) hasil perhitungan 0,000 $<0,01$ maka artinya ada hubungan yang signifikan (berarti) antar variabel ini.

7. Hubungan variabel penilaian penyampaian pesan-pesan politik dengan perilaku pemilih memiliki korelasi sedang; tingkat kekuatan hubungan cukup kuat. Angka koefisien korelasi bernilai positif sehingga hubungan kedua variabel tersebut bersifat searah (jenis hubungan searah). Karena nilai sig. (2-tailed) hasil perhitungan $0,000<0,01$ maka artinya ada hubungan yang signifikan (berarti) antar variabel ini. 
8. Hubungan variabel penilaian isi/muatan pada penyampaian pesan-pesan politik dengan perilaku memilih memiliki korelasi sedang; tingkat kekuatan hubungan cukup kuat. Angka koefisien korelasi bernilai positif sehingga hubungan kedua variabel tersebut bersifat searah (jenis hubungan searah). Karena nilai sig. (2-tailed) hasil perhitungan $0,000<0,01$ maka artinya ada hubungan yang signifikan (berarti) antar variabel ini.

Dari ketiga pengujian yang dilakukan pada penelitian ini, kombinasi terpaan media, penggunaan media massa, dan penggunaan saluran antarpribadi secara ilmiah telah membuktikan hipotesis yang diajukan di awal penelitian ini, bahwa kampanye politik yang dilakukan pasangan kandidat Mursil-tengku Insyafuddin berpengaruh terhadap perilaku pemilih pada Pilkada Aceh Tamiang tahun 2017. sebagai suatu alat untuk menyampaikan informasi, penilaian, dan gambaran umum tentang banyak hal, media memang mempunyai kemampuan berperan sebagai pembentuk opini publik, antara lain karena media juga dapat berkembang menjadi kelompok penekan atas suatu ide atau gagasan, dan bahkan suatu kepentingan atau citra yang ia representasikan untuk diletakkan dalam suatu konteks kehidupan yang lebih empiris (Sobur, 2002: 31). Namun demikian, efek dari kampanye politik yang dilakukan sebenarnya tidak hanya dipengaruhi oleh frekuensi atau intensitas paparan tetapi juga muatan dan substansi dari komunikasi yang dilakukan (Mujani dan Liddle, 2010).

\section{KESIMPULAN}

Penelitian pengaruh kampanye politik terhadap perilaku memilih dalam kajian ini menemukan beberapa kesimpulan, sebagai berikut:

1) Bahwa kampanye politik pasangan kandidat Mursil-Tengku Insyafuddin secara simultan memengaruhi perilaku pemilih pada Pilkada Aceh Tamiang tahun 2017. Nilai keeratan 
hubungan antar variabel berada di rentang rendah sampai dengan sedang dengan tingkat hubungan yang signifikan.

2) Kampanye politik memberikan pengaruh terhadap pengenalan figuritas pasangan kandidat Mursil-Tengku Insyafuddin secara signifikan.

3) Pada pemahaman partai politik pengusung pasangan kandidat, kampanye politik secara simultan memberikan pengaruh secara signifikan.

4) Kampanye politik secara simultan memberikan pengaruh terhadap sikap pemilih mengenai citra pasangan kandidat secara signifikan.

\section{DAFTAR PUSTAKA}

Aan, Munawar S. (2013). Metode Riset Kuantitatif Komunikasi. Yogyakarta: Pustaka Pelajar.

Agustino, Leo. (2009). Pilkada dan Dinamika Politik Lokal. Yogyakarta: Pustaka Pelajar

Ardial. (2010). Komunikasi Politik. Jakarta: PT. Indeks

Ardianto, Elvinaro \& Komala, Lukiati E. (2005). Komunikasi Massa Suatu Pengantar. Bandung: Simbiosa Rekatama Media.

Ardianto, Elvinaro \& Q. Anees, Bambang. (2007). Filsafat Ilmu Komunikasi. Bandung: Simbiosa Rekatama Media.

Aribowo, Agus. (2013). Bauran Pemasaran Politik, Peristiwa Mutakhir, dan Julukan Diri dalam Meningkatkan Citra Kandidat Serta Implikasinya Terhadap Keputusan Memilih. Tugiman, Hiro., Ria Ratna, Sucherly, Wilson Bangun, \& Marcellia Susan (editor). Perkembangan Kewirausahaan dan Tantangannya dalam Menghadapi Perekonomian Indonesia di Masa yang Akan Datang: Proceeding Seminar Nasional Fakultas Ekonomi tanggal 19-20 Juni 2013 di Universitas Kristen Maranatha Bandung.

Azwar, S. (2007). Metode Penelitian. Yogyakarta: Pustaka Pelajar.

Bajari, Atwar. (2015). Metode Penelitian Komunikasi; Prosedur, Tren, dan Etika. Bandung: Simbiosa Rekatama Media

Bawaslu RI. (2017). Indeks Kerawanan Pemilu: Pemilihan Kepala Daerah Tahun 2017. Jakarta: Bawaslu RI. 
Bawono, Muhammad. (2008). Persepsi dan Perilaku Memilih terhadap Partisipasi Politik dalam Pemilihan Umum Legislatif 2004 di Kabupaten Nganjuk. Tesis magister tidak dipublikasikan. Surakarta: Universitas Sebelas Maret.

Budiardjo, Miriam. (2008). Dasar-dasar Ilmu Politik (Edisi Revisi). Jakarta: PT Gramedia Pustaka Utama

Cangara, Hafied. (2016). Komunikasi Politik; Konsep, Teori, dan Strategi (Edisi Revisi). Jakarta: PT. Raja

Grafindo Persada

Calise, Mauro \& Lowi, Theodore J. (2010). Hyperpolitics: An Interactive Dictionary of Political Science Concept. Chicago: The University of Chicago

Caplan, Bryan. (2007). The Myth of the Rational Voter; Why Democracies Choose Bad Policies (Executive Summary). Diunduh tanggal 21 Mei 2018. Sumber: https://object.cato.org/pubs/pas/pa594.pdf

Chafee, Steven H. (2001). Studying the New Communication of Politics. Taylor \& Francis Journal of Political Communication Volume 18, 2001.

Darmadi, Durianto., Sugiarto, \& Tony Sitinjak. (2001). Strategi Menaklukkan Pasar Melalui Riset Ekuitas Merek dan Perilaku Merek. Jakarta: PT. Gramedia Pustaka Utama.

Effendy, Onong U. (2006). Ilmu Komunikasi; Teori dan Praktek (Edisi 16). Bandung: PT. Remaja Rosdakarya.

Elvinaro A., Komala, Lukiati, \& Siti Karlinah. (2007). Komunikasi Massa Suatu Pengantar (Edisi Revisi). Bandung: Simbiosa Rekatama Media.

Firmanzah. (2008). Marketing Politik; Antara Pemahaman dan Realitas. Jakarta: Yayasan Obor Indonesia. . (2010). Mengelola Partai Politik; Komunikasi dan Positioning, Ideologi Politik dan Era Demokrasi. Jakarta: Yayasan Obor Indonesia.

Gama, Bety \& Widarwati, Nunun Tri. (2008). Hubungan antara Kampanye Kandidat Kepala Daerah dan Perilaku Pemilih Partisipasi Politik Wanita (Studi pada Ibu-Ibu Rumah Tangga dalam Pelaksanaan Pemilihan Kepala Daerah di Kabupaten Sukoharjo). Jurnal Ilmiah Scriptura, Volume 2, Nomor 1, Januari 2008.

Guilford, J.P. (1956). Fundamental Statistics in Psychology and Education. New York: McGraw-Hill.

Halik, Abdul. (2017). Eksistensi Simbolik Aktivisme Komunikasi Politik (Refleksi Pertukaran Songkok Bone Jokowi dan Blangkon Jusuf Kalla pada Sidang Tahunan MPR RI, 16 Agustus 2017. Jurnal Komodifikasi, Volume 5, Juni 2017, hal. 1-14.

Harifin, Kurniawati M. (2012). Pengaruh Personal Branding dan Positioning terhadap Perilaku Pemilih dalam Pemilukada di Kabupaten Bone Bolango - Gorontalo. Jurnal Ilmu Politik, Volume 3, Nomor 1, April 2012.

Haryanto. (2014). Kebangkitan Party ID: Analisis Perilaku Memilih dalam Politik Lokal di Indonesia. Jurnal Ilmu Sosial dan Ilmu Politik Volume 17 Nomor 3, Maret 2014. 
Hasan, Kamaruddin. (2009). Komunikasi Politik dan Pencitraan (Analisis Teoritis Pencitraan Politik di Indonesia). Jurnal online "Dinamika" Volume 2 Nomor 4 Tahun 2009. Palembang: FISIP Universitas Baturaja.

Hikmat, Mahi M. (2014). Metode Penelitian dalam Perspektif Ilmu Komunikasi dan Sastra. Jakarta: Penerbit Graha Ilmu.

Hutapea, Rinto P. (2015). Faktor-Faktor Yang Mempengaruhi Pilihan Masyarakat Pada Pemilihan Bupati Dan Wakil Bupati Toba Samosir Tahun 2015. Tesis magister tidak dipublikasikan. Medan: Universitas Sumatera Utara.

Jefkins, Frank. (1995). Periklanan (Edisi ketiga). Jakarta: Penerbit Erlangga.

Khairil. (1994). Hubungan Keterdedahan Petani Anggota Kelompencapir pada Siaran Perdesaan dari Radio dan Televisi dengan Pengetahuan Mereka Tentang Diversifikasi Usahatani di Kabupaten Bengkulu Utara. Tesis magister tidak dipublikasikan. Bogor: Institut Pertanian Bogor.

Kamus Besar Bahasa Indonesia versi daring (www.kbbi.web.id)

Karlina, Nita. (2013). Faktor-faktor Yang Mempengaruhi Masyarakat Kota Bandung dalam Memilih Calon Gubernur dan Calon Wakil Gubernur pada Pemilihan Kepala Daerah Jawa Barat 2013. Skripsi sarjana tidak dipublikasikan. Sumedang: Universitas Padjadjaran

Karlinah, Siti. (1999). Komunikasi Massa. Jakarta: Penerbit Universitas Terbuka

Keputusan Komisi Independen Pemilihan Kabupaten Aceh Tamiang Nomor 86 Tahun 2016 Tentang Perubahan Atas Keputusan Komisi Independen Pemilihan Kabupaten Aceh Tamiang Nomor 01/Kpts/KIP-Kab.001434600 Tahun 2016 Tentang Tahapan, Program, dan Jadwal Penyelenggaraan Pemilihan Bupati dan Wakil Bupati Aceh Tamiang Tahun 2017.

Keputusan Komisi Independen Pemilihan Kabupaten Aceh Tamiang Nomor 135/Kpts/KIPKab.001434600 Tahun 2017 Tentang Penetapan Pasangan Calon Bupati dan Wakil Bupati Terpilih dalam Pemilihan Bupati dan Wakil Bupati Aceh Tamiang Tahun 2017.

Kotler, Philip. (2002). Marketing Management, Millenium Edition ( $1^{\text {st }}$ book). New Jersey, USA: Pearson Education Publisher.

Kotler, Philip \& Keller, Kevin L. (2009). Manajemen Pemasaran (Jilid 1 Edisi ke 13). Jakarta: Penerbit Erlangga.

Kriyantono, Rachmat. (2014). Teknik Praktis Riset Komunikasi. Jakarta: Penerbit Kencana.

Lees-Marshment, Jennifer. (2001). Comprehensive Political Marketing; Global Political Parties, Strategy and Behaviour. London: Routledge.

Liliweri, Alo. (2011). Komunikasi Serba Ada Serba Makna. Jakarta: Penerbit Kencana.

Lilo, Herman \& Sultan, M. Iqbal. (2011). Pengaruh Kampanye Program Kegiatan Sosial Partai Demokrat Terhadap Pemilih Petani dalam Pemilu Legislatif 2009 di Kabupaten Soppeng. Jurnal Kareba, Volume 1 Nomor 2 Tahun 2011.

Littlejohn, Stephen W. \& Foss, Karen A. (editor). (2016). Ensiklopedia Teori Komunikasi (Jilid 1\& 2). Jakarta: Penerbit Kencana. 
Makalunsenge, Idrus., Boham, Antonius., \& Ridwan Paputungan. (2014). Pengaruh Reklame Politik Pilwako Terhadap Sikap Pemilih Pemula di Kelurahan Gogagoman Kecamatan Kotamobagu Barat. Jurnal Acta Diurna, Volume III Nomor 3 Tahun 2014.

Maran, Rafael Raga. (2014). Pengantar Sosiologi Politik. Jakarta: Rineka Cipta

Margaretha, Yessy. (2011). Media Massa dan Tindakan Memilih: Studi Peran Media Massa terhadap Tindakan Memilih Masyarakat dalam Pemilihan Kepala Daerah Kabupaten Karo Periode 2010 2015. Skripsi sarjana tidak dipublikasikan. Medan: Universitas Sumatera Utara.

Martha, Layung Pramesti. (2015). Hubungan Penggunaan Sumber Informasi Kampanye dan Partisipasi Politik; Kasus Pilpres 2014 di Kecamatan Cibinong Bogor. Tesis magister tidak dipublikasikan. Bogor: Institut Pertanian Bogor

McNair, Brian. (2003). An Introduction to Political Communication. London: Routledge.

McQuail, Denis. (2010). Teori Komunikasi Massa McQail (Edisi 6 Buku 2). Jakarta: Penerbit Salemba Humanika.

McQuail, Denis \& Windahl, Sven. (1984). Communication Model for the Study of Mass Communications. New York: Longman Inc.

Miaz, Yalvema. (2012). Partisipasi Politik; Pola Perilaku Pemilih Pemilu Masa Orde baru dan Reformasi. Padang: UNP Press.

Moleong, Rexy J. (2006). Metodologi Penelitian Kualitatif. Bandung: PT. Remaja Rosdakarya.

Mulyana, Deddy. (2015). Ilmu Komunikasi Suatu Pengantar (Edisi 19). Bandung: PT. Remaja Rosdakarya.

Mujani, Saiful dan Liddle, R. William. (2010). Personalities, Parties, and Voters. Journal of Democracy Volume 21 Nomor 2 Tahun 2010. National Endowment for Democracy and The Johns Hopkins University Press.

Nimmo, Dan. (2006). Komunikasi Politik; Khalayak dan Efek. Bandung: PT. Remaja Rosdakarya.

Ningsih, Tri Maulia. (2014). Kualitas Demokrasi pada Pemilihan Umum Kepala Daerah Aceh Tamiang 2012 (Studi Kasus Pemilihan Umum Kepala Daerah Aceh Tamiang 2012). Skripsi sarjana tidak dipublikasikan. Medan: Universitas Sumatera Utara.

Nurbasari, Anny. (2013). Pengaruh Pemasaran Politik terhadap Keputusan Memilih Walikota Bandung. Prosiding Seminar Nasional Fakultas Ekonomi: "Effective Strategic Planning to Enhance Local Government Accoutibility and Performance”. November 2013, Hal. 153-180. Banjarmasin: Universitas Lambung Amangkurat.

Nurdin, Ali. (2011). Studi perilaku Pemilih di Indonesia: Fenomena Pemilih Rasional-Pragmatis. Makalah tidak dipublikasikan. Diunduh pada 16 Juni 2017. Sumber: https://www.academia.edu/12247359/Studi_Perilaku_Memilih_di_Indonesia_Fenomena_Pemili $\underline{\text { h_Rasional-Pragmatis }}$

Nursal, Adman. (2004). Political Marketing Strategi Memenangkan Pemilu; Sebuah Pendekatan Baru Kampanye Pemilihan DPR, DPD, Presiden. Jakarta: PT. Gramedia Pustaka Utama. 
Nuruddin. (2007). Pengantar Komunikasi Massa. Jakarta: Raja Grafindo Persada

Pito, Toni Adrianus., Efriza, \& Kemal Fasyah. (2013). Mengenal Teori-teori Politik; Dari Sistem Politik Sampai Korupsi. Bandung: Nuansa Cendikia

Puspasari, Tri Setya. (2012). Faktor-faktor yang Mempengaruhi Perilaku Pemilih dalam Pemilihan Umum Kepala Daerah Provinsi Banten 2011 di Kecamatan Karawaci Kota Tangerang. Skripsi sarjana tidak dipublikasikan. Serang: Universitas Sultan Ageng Tirtayasa.

Peraturan Komisi Pemilihan Umum (KPU) Nomor 7 Tahun 2015 Tentang Kampanye Pemilihan Gubernur dan Wakil Gubernur, Bupati dan Wakil Bupati dan/atau Walikota dan Wakil Walikota.

Peraturan Komisi Pemilihan Umum (KPU) Nomor 12 Tahun 2016 Tentang Perubahan Atas Peraturan KPU Nomor 7 Tahun 2015 Tentang Kampanye Pemilihan Gubernur dan Wakil Gubernur, Bupati dan Wakil Bupati dan/atau Walikota dan Wakil Walikota.

Prasetyo, Budi. (2012). Partisipasi Politik Masyarakat dalam Pemilihan Kepala Daerah Langsung di Desa Wonokampir Kecamatan Watumalang Kabupaten Wonosobo Tahun 2010. Skripsi tidak dipublikasikan. Salatiga: Program Studi PPKn, Fakultas Keguruan dan Ilmu Pendidikan Universitas Kristen Satya Wacana.

Purwosusanto, Hery. (2011). Komunikasi Pemasaran Politik Partai Islam: PKS dalam Pemilu Legislatif. Jakarta: Penerbit Zaman.

Rakhmat, Jalaluddin. (2002). Metode Penelitian Komunikasi. Bandung: Remaja Rosdakarya.

Rakhmat, Jalaluddin. (2007). Psikologi Komunikasi (Edisi revisi). Bandung: Remaja Rosdakarya.

Rakhmat, Jalaluddin \& Ibrahim, Idi Subandy. (2016). Metode Penelitian Komunikasi (Edisi Revisi kedua). Bandung: Simbiosa Rekatama Media.

Reddi, C. (2009). Effective Public Relations and Media Strategy. New Delhi: PHI Learning Private Limited.

Ritzer, George. (2012). Teori Sosiologi Modern. Jakarta: Penerbit Kencana.

Rosit, Muhammad. (2012). Strategi Komunikasi dalam Pilkada (Studi Kasus Pemenangan Pasangan Kandidat Ratu Atut dan Rano Karno pada Pilkada Banten tahun 2011). Tesis tidak dipublikasikan. Jakarta: Departemen Ilmu Komunikasi, Fakultas Ilmu Sosial dan Ilmu Politik Universitas Indonesia

Rosady, Ruslan. (1997). Kiat dan Strategi Kampanye Public Relation. Jakarta: PT. Raja Grafindo Persada.

Roth, Dieter. (2008). Studi Pemilu Empiris: Sumber, Teori, Instrumen, dan Metode. Jakarta: FriedrichNaumann Stiftung fur die Freiheit

Rubyanti, Rika. (2009). Pengaruh Popularitas Terhadap Pilihan Pemilih Pemula Studi Kasus Mahasiswa Departemen Ilmu Politik FISIP USU. Skripsi tidak dipublikasikan. Medan: Departemen Ilmu Politik, Fakultas Ilmu Sosial dan Ilmu Politik Universitas Sumatera Utara. 